\title{
TAKING LAW INTO THEIR OWN HANDS: UNOFFICIAL AND ILLEGAL SANCTIONS BY THE PAKISTANI TRIBAL COUNCILS
}

\section{INTRODUCTION}

In June 2002, a Pakistani tribal village council sentenced a woman to be gang raped in order to restore the honor of an opposing tribe. It is unfathomable that such an atrocious human rights violation could be rendered as a form of punishment in a civilized country. In order to understand how something like that could happen in the twenty-first century, one only need look at the state of Pakistani law and order, or the lack thereof. ${ }^{2}$

This Note will look at the historical effects that led up to the present-day determination that the country is in a state of lawlessness. ${ }^{3}$ More importantly, this Note will look at the effects on the Pakistani culture and society when such inhumane punishment is ordered by the tribal justice system. An analysis will be conducted to determine what role these tribal councils play as an alternative to the official court system in resolving disputes and how some of the remedies sanctioned by the council are in conflict with the Pakistan Constitution. In addition, this Note will compare how India officially utilizes the tribal councils within their society for the purpose of illustrating how Pakistan could utilize a tribal jury system effectively and officially. Finally, this Note will analyze whether the tribal councils should be abolished or reformed. ${ }^{4}$

1. See Muhammad Saleem Sheikh, The Meerwala Incident: Shame in the Name of Justice, YOU (July 26, 2002), available at http://www.jang-group.com/thenews/jul2002weekly/you-16-07-2002.html (last visited Jan. 19, 2003).

2. See id. This type of court system, the jirga, is not legal but is maintained by tribal leaders to uphold their feudal authority. See Criminology Research Institute, Punjabi Gang Rape Victim Fears For Her Life After Six Are Sentenced to Hang, available at http://www.thecriminologist.com/cri_news/gang_rape.asp (last visited Nov. 19, 2002) [hereinafter CRI]. What makes it difficult for the police to act against this type of justice, is that the local police officers will do little if nothing to prevent such trials from occurring and are more likely to help by covering up evidence of the tribal proceedings. See id. However, this brutal example of medieval justice has prompted the Pakistani Government to take action after the public and human rights organizations outcry against this violation. See id.

3. See AZhar Hassan NadeEM, Pakistan: The PoltTiCal Economy of LaWlessness 1-2 (2002).

4. Several other factors will be addressed in dealing with the much larger issue of lawlessness. However, these issues will only be briefly discussed to allow the majority of the discussion to focus on the interaction between the State and the tribal councils. 


\section{INCIDENT OF GANG-RAPE}

In June 2002, a human rights atrocity occurred in the Punjab ${ }^{5}$ province of Pakistan when a young woman from the Gujjar tribe ${ }^{6}$ was sentenced to a gang rape in order to restore the honor of another woman from the Mastoi tribe.? An unofficial tribal jury, armed with machine guns, laid down the sentence in order to punish the victim's twelve-year-old brother. ${ }^{8}$ The victim's brother was allegedly having an illicit affair with a Mastoi woman, who was from a tribe of a higher caste. ${ }^{9}$ It was later proven that the alleged affair was simply a cover-up by the Mastoi tribe after several tribal members kidnapped, beat, and sodomized the young boy. ${ }^{10}$ They held the boy captive until the boy's uncle requested the boy's captivity be resolved before a tribal council or what is commonly referred to as a panchayat in Pakistan. ${ }^{11}$ Although the victim's father offered to allow the boy to marry the Mastoi woman, the Mastoi tribe rejected this offer because the boy was from a lower caste. ${ }^{12}$ Subsequently, the panchayat decided that the aggrieved family members of the higher caste could be restored after members of the Mastoi tribe disgraced a member of the boy's family. ${ }^{13}$ The young Gujjar woman had been at the court to seek leniency for her brother, but immediately after the ruling, four Mastoi

5. See generally Government of Punjab, at http://www.punjab.gov.pk.html (last visited Jan. 19, 2003). Punjab is located in the northern region of the country, and is also the most populous province of Pakistan. See id.

6. See Human Rights Watch, Pakistan: Tribal Councils Source of Abuse, July 12, 2002, available at http://www.hrw.org/press/2002/07/pak0712.htm (last visited Jan. 19, 2003). The Gujjar tribe is located in the village of Meerwala, which is located in southern Punjab. See id.

7. See Sadaf Zahra, Rape Cases Highlight Terrible Plight of Women in Pakistan, at http://www.marxist.com/women/pakistan_rape_cases.html (last visited Mar. 14, 2003).

8. See Brian Bennett, A Violation of Justice, in TIME - AsIa MAGAzINE, July 15, 2002, available at http://www.time.com/time/asia/magazine/article/0,13673,501020715300692,00 .html (last visited Nov. 19, 2002). The brother was accused of having sexual relations with a twenty-two year old woman of the higher caste Mastoi tribe. See CRI, supra note 2. Various news reports have conflicting ages for the woman's brother ranging from age eleven to fourteen years old. See Zahra, supra note 7.

9. See id.

10. See Amnesty International, Pakistan - The Tribal Justice System (Aug. 1, 2002), available at http://web.amnesty.org/ai.nsf/Index/ASA330242002?OpenDocument\&of=COUNTRIES\% 5CPAKISTAN (last visited Jan. 19, 2003) [hereinafter Amnesty].

11. See id. Tribal village councils are also called panchayats in the south and jirgas in the north and will be used interchangeably throughout this Note. See Tribal Law System on Trial After Rape-by-Decree, available at http://www.smh.com.au/articles/2002/07/07/102566708 8892.html (last visited Nov. 19, 2002) [hereinafter Tribal System on Trial].

12. See Associated Press, The Cancer of Tribalism, available at http://www.khilafah.com/home/category.php? DocumentID=4508\&TagID=12 (last visited Nov. 19,2002 ). There is great prestige for a family to conclude a marriage for a daughter with a higher-ranking caste; however, much shame or dishonor is brought if the daughter is married to an inferior caste level. See id.

13. See CRI, supra note 2. 
tribesmen dragged her to a nearby hut and repeatedly raped her. ${ }^{14}$ While this by itself is extremely disturbing, even more appalling was the fact that the young victim, who happened to teach the Quran ${ }^{15}$ to the Mastoi tribe's children, pleaded for mercy as several hundred villagers stood outside the hut and jeered and laughed while she was being gang-raped. ${ }^{16}$ After the horrendous ordeal, the woman was forced to return home by walking naked through the village; under the Pakistan Penal Code, being in public in a state of undress is a crime in itself. ${ }^{17}$

This story only became public after a local reporter heard about the atrocious act and subsequently published the story in a local newspaper. ${ }^{18}$ Upon hearing about this ordeal, Pakistan's President, Pervez Musharraf, ${ }^{19}$ and the Pakistani Supreme Court ${ }^{20}$ ordered the local police to apprehend the offenders. $^{21}$ Additionally, many human rights organizations voiced their outrage at this horrible human rights violation. ${ }^{22}$

Although the victim filed a complaint with the local police, it was not until one week later that the police arrested any suspects in the gang rape. ${ }^{23}$ Subsequently, a member of the police force was arrested for failing to file a

14. See Press Release, Amnesty International, Pakistan: Tribal Councils Must Stop Taking Law Into Their Own Hands, (July 5, 2002), available at http://web.amnesty.org/ai.nsf/ Index/ASA330182002? OpenDocument \&of=COUNTRIESIPAKISTAN (last visited Jan. 19, 2003) [hereinafter Amnesty Press Release].

15. See Rachel Ruane, Murder in The Name of Honor: Violence Against Women in Jordan and Pakistan, 14 EMORY INT'L L. REV. 1523, 1579 (2000). The Quran is the primary material source of the word of God as revealed to the Prophet and it is also a source of Islamic guidance. See id.

16. See CRI, supra note 2 . It must be assumed that the local police were aware of the event and did nothing to stop it. See Amnesty Press Release, supra note 14.

17. See Amnesty, supra note 10 . There are a large number of public stripping of women and parading them naked through southern Punjab and upper Sindh region. See id. The intended target of humiliation the majority of the time is the woman's male relatives. See id. Section 354A Pakistan Penal Code (PPC) makes it unlawful to be public in a state of undress. See id.

18. See Zahra, supra note 7.

19. See Islamic Republic of Pakistan, Basic Facts, available at http://www.pak.gov.pk/public/govt/basic_facts.html (last visited Jan. 19, 2003) [hereinafter Pakistan Basic Facts]. In October 1999, Army Chief of Staff General Pervez Musharraf overthrew the civilian government in a nonviolent coup and named himself Chief Executive. See U.S. Dep't of State, 2001 Pakistan Country Reports on Human Rights Practices, (Mar. 4, 2002), available at http://www.state.gov/g/drl/rls/hrrpt/2001/sa/8237pf.htm (last visited Jan. 19, 2003) [hereinafter U.S. Dep't of State]. Musharraf was sworn in as the country's President on June 20, 2000. See id.

20. See Islamic Republic of Pakistan, Judiciary, available at http://www.pak.gov.pk/public/govt/judiciary.htm (last visited Jan. 19, 2003). The Supreme Court has a limited degree of independence and is somewhat controlled by President Mushaffar and his government. See U.S. Dep't of State, supra note 19.

21. See Tribal System on Trial, supra note 11. The Supreme Court ordered a probe into the sexual assault on the tribal girl after the country was outraged. See id. The Supreme Court also inquired as to why the police took so long to register the case. See Sheikh, supra note 1.

22. See id. See Amnesty, supra note 10.

23. See Sheikh, supra note 1. 
report of the woman being gang-raped. ${ }^{24}$ Local human rights activists accused the police of knowing about the tribal council meeting, but then failing to stop the attack on the woman. ${ }^{25}$

Pakistani officials brought the suspected rapists, as well as some members of the tribal council, to trial in the Anti-Terrorism Court (ATC). ${ }^{26}$ The ATC was created under the Anti-Terrorism Act of 1997 in order to expedite criminal trials so they are completed within thirty days. ${ }^{27}$ Because the panchayat is not an official court and Punjab is not one of the federally recognized tribal areas subject to their own rule, the rapists could not claim that their tribal law was sovereign, and they were, therefore, immune to prosecution. ${ }^{28}$ However, one of the accused did try to prove his innocence by claiming that the woman was given to him in marriage and therefore there was no violation of rape. ${ }^{29}$ Ultimately, the ATC found six of the fourteen arrested guilty and sentenced them to death. ${ }^{30}$

\section{ANALYSIS OF PAKISTANI LAW AND ORDER}

It is arguable that Pakistan is not a civilized country, but rather is in a primitive state. ${ }^{3 !}$ One comparison between the two terms "primitive"32 and

\section{See id.}

25. See Amnesty Press Release, supra note 14. It is hard to believe that the police were not aware of what was happening with the reports that hundreds of villagers jeered and laughed outside the hut as the girl was gang-raped. See id.

26. See CRI, supra note 2. The Law Minister of Pakistan arranged for the trial to take place in a specially convened Anti-Terrorist Court because he recognized the threat of interference and possible reprisals by the local tribal members. See id.

27. See HASAN-ASKARI RIzvi, MilTtaRY, STATE AND SOCIETY IN PAKISTAN 227 (2000). The ATC is empowered to try acts against the state, conspiracy, kidnapping, and particular "heinous" crimes such as gang-rape and child killings. See U.S. Dep't of State, supra note 19.

28. See Six Men Guilty in Gang-Rape Trial, THE HAMILTON SPECTATOR, Sept. 3, 2002, available at 2002 WL 24456633. The tribal areas disregard federal law for their own clan justice. See id.

29. See id. Rape is only illegal when the sexual intercourse occurs between two individuals who are not married. See id. Pakistan does not have a spousal rape law so the rapist claiming this could have been acquitted if the judge had accepted this testimony. See id.

30. See CRI, supra note 2. The four rapists and two tribal members were sentenced to death while other council members were acquitted. See id. The remaining eight defendants were acquitted. See id. Unbelievably, this is the first time that a tribal jury has been punished for their sanctions. See Sami Zubeiri, Pakistani Tribal Justice Under Attack As Rapists Get Death Penalty, AGENCE FRANCE-PRESSE, Sept. 1, 2002, available at 2002 WL 23590875.

31. See Craig Baxter, Introduction in ZIA's PAKISTAN 1-2 (Craig Baxter ed. 1985). Such a form of government transformed from the Western parliamentary system to a one-ruler Islamic state presents political, economic, and social questions. See id.

32. See Merriam-Webster's NinTh New Collegiate Dictionary 934 (1985). Primitive is defined as "a: of or relating to the earliest stage or period[;] b: closely approximating an early ancestral type; little evolved[;] c: belonging to or characteristic of an early stage of development." Id. 
civilized"33 indicates that the former is generally where the people identify themselves by a particular blood relationship, whereas in the latter, the people define themselves in terms of relation to a given territory. ${ }^{34}$

Typically, there are two forms of government. ${ }^{35}$ The first form, social organization, or society, is analyzed by how the government deals with the people in their capacity as members of tribal groups. ${ }^{36}$ The second form, political organization, is based on a territorial state whereby the government deals with the constituents as a region. ${ }^{37}$ The rural area of Pakistan consists primarily of tribes that are organized on the basis of kinship with each tribe functioning as a simple society with tribal governments. ${ }^{38}$ This has been equated with a primitive government. ${ }^{39}$ This varies from a higher civilization where one would find multiple cultures living under the same authority. ${ }^{40}$

\section{A. Historical Aspect}

As a result of the partitioning of British India, ${ }^{41}$ Pakistan was formed on August 14, 1947..$^{42}$ However, many conflicts arose between the Pakistan refugees that came from Afghanistan and India and the traditional rural tribal people who already inhabited Pakistan. ${ }^{43}$ The typical village in Pakistan is divided into separate factions based upon kinship, ethnic, ideological, or class rationales. ${ }^{44}$

Many of the country's punishments, such as amputation, whipping, and stoning, have been sanctioned for decades. ${ }^{45}$ These punishments are viewed by modern societies as barbaric and uncivilized. ${ }^{46}$ The Human Rights

33. See id. at 244. Civilized is defined as "to cause to develop out of a primitive state; specif: to bring to a technically advanced and rationally ordered stage of cultural development." Id.

34. See I. Schapera, Government and Politics In Tribal Societies 3 (1967).

35. See id.

36. See id.

37. See id. Regions are treated much like a town or a state. See id.

38. See id.

39. See SCHAPERA, supra note 34 , at 3.

40. See id. at 19.

41. See Introduction in PAKISTAN: A COUNTRY STUDY, XIX (1975). The partitioning of British India created two separate states of India and Pakistan. See id. Prior to this, the area was accompanied by communal riots of unprecedented violence between the Hindu and Muslims. See id.

42. See Surjit Mansingh, Historical Setting, in Pakistan: A CounTry STUdy, 32 (Richard F. Nyrop, 5th ed. 1984). Pakistan was formed for the Muslim refugees in order to separate the Indian Hindus from those individuals with Muslim beliefs. See id. at 26-27. Religion was the key force behind the drive for a separate state. See P.A. Kluck, The Society and Its Environment, in id. at 78.

43. See id. at 33.

44. See Charles H. Kennedy, Rural Groups and the Stability of the Zia Regime, in ZIA'S PAKISTAN, supra note 31 , at 28.

45. See Baxter, supra note 31 , at 1.

46. See id. 
Commission of Pakistan (HRCP) ${ }^{47}$ stated that the informal justice the tribal councils provide is simply the tribe taking the law into their own hands and rendering justice in a medieval way. ${ }^{48}$

The state of lawlessness has been present since the Islamic Republic of Pakistan was formed. ${ }^{49}$ Ethnic, regional, or sectarian conflicts factored in the breakdown of social order in Pakistan. ${ }^{50}$ The State's failure to manage and meet the demands of minority groups drove the tribal areas to change their focus from demanding cultural and political autonomy to seeking territorial sovereignty. ${ }^{51}$

The majority of Pakistan people live in the rural areas as opposed to the urban cities. ${ }^{52}$ According to the 1981 census, seventy-one percent $(71 \%)$ of Pakistan's population lived in a village with fewer than 5000 inhabitants. ${ }^{53}$ Pakistan's rural areas suffer from extremely rapid population growth. ${ }^{54}$ The major source of this growth is the influx of refugees from Afghanistan and India. ${ }^{55}$ Subsequently, such rapid growth played havoc on rural development plans and placed severe demands on an already inefficient local government structure. $^{56}$

The military and civilian rulers created authoritarian measures to oppress the citizens of Pakistan. ${ }^{57}$ As a result, several decades of economic and social inequality burdened the development of a democratic regime over a heterogeneous population. ${ }^{58}$ In 1981 , while the State was under martial law,

47. See generally HuMAN RIGHTS COMM'N OF PAKISTAN, available at http://www.hrcp .cjb.net (last visited Jan. 19, 2003) [hereinafter HRCP]. HRCP is a non-governmental organization (NGO) set up to work for the ratification and implementation of the Universal Declaration of Human Rights and other internationally adopted human rights initiatives; to promote studies in the field of human rights; to cooperate and aid with national and international groups engaged in the promotion of human rights; and to take appropriate action to prevent violations of human rights and provide legal aid to victims of human rights violations. See id.

48. See Amnesty, supra note 10.

49. See NADEEM, supra note 3 , at 131 .

50. See id. at 37.

51. See Ian Talbot, InVEnting the Nation India \& Pakistan 283 (2000). As early as 1948, the tribal chiefs sought their own independent state, but their demands were quickly denied as the Pakistan military took action against the rural tribes who then acceded to governance by Pakistan. See Mansingh, supra note 42, at 34 .

52. See Kennedy, supra note 44, at 23.

53. See id. at 23-24.

54. See PAKISTAN MINISTRY OF FINANCE, 2001 Economic Survey, available at http://www.finance.gov.pk/survey/main.html (last visited Jan. 19, 2003) [hereinafter 2001 Economic Survey].

55. See Kennedy, supra note 44 , at 24 . Afghanistan and India are neighboring countries to Pakistan. See id.

56. See id.

57. See Omar Asghar Khan, Critical Engagements: NGO's and the State, in POWER AND Civil SocieTY IN PAKISTAN 278 (Anita M. Weiss \& S. Zulfiqar Gilani eds., 2001).

58. See TALBOT, supra note 51, at 286. 
Zia ul-Haq ${ }^{59}$ replaced sections of the 1973 Constitution with a Provisional Constitutional Order that required the judiciary to be subordinate to the military. ${ }^{60}$ The current federal justices were forced to take a new oath or else lose their position on the court. ${ }^{61}$ Several judges lost their jobs because they would not accept the fact that the courts were under the military's power. ${ }^{62}$

In 1985, Pakistan adopted the United Nations Convention on the Prevention of Crime and the Treatment of Offenders. ${ }^{63}$ This UN Convention stated, "certain forms of crime can hamper the political, economic, social and cultural development of peoples and threaten human rights, fundamental freedoms, and peace, stability and security." ${ }^{64}$ By adopting this Convention, Pakistan agreed to strengthen crime prevention programs and undertake a criminal justice process that is responsive to the diversity of political and economic systems as well as the ever-changing conditions of society. ${ }^{65}$ Despite Pakistan's adoption of this Convention, it is doubtful that Pakistan has adequate programs in place to change social conditions. ${ }^{66}$

During the early 1990s, maintaining law and order was no longer a priority in Pakistan. ${ }^{67}$ This resulted in violence and corruption. ${ }^{68}$ In addition, the resolution of judicial matters became increasingly difficult. ${ }^{69}$ During this time, the Pakistani government routinely denied its human rights abuses. ${ }^{70}$ Nevertheless, Pakistan was quick to publicize the deteriorating human rights situation in the valley of Kashmir. ${ }^{71}$

By the early 1990s, institutional life was so underdeveloped and weakened that the tribal areas disregarded the authority of the State. ${ }^{72}$ The basic administration of the area, such as census taking, school regulation, and taxation, had been interrupted. ${ }^{73}$ Yet, without the interference of federal governmental administration, the tribal people were able to survive in a state

59. See Baxter, supra note 31, at 1 . General Muhammed Zia ul-Haq assumed power in 1977 when his military associates overthrew the government of Prime Minister Zulfiqar Ali Bhutto. See id.

60. See RIzVI, supra note 27 , at 178.

61. See id.

62. See id.

63. See NADEEM, supra note 3 , at 2-3.

64. See id.

65. See id.

66. See U.S. Dep't of State, supra note 19.

67. See NADEEM, supra note 3, at 47.

68. See id.

69. See id.

70. See TALBOT, supra note 51, at 278.

71. See id.

72. See id. at 222. Pakistan tribes in the rural areas have always maintained a fair amount of autonomy where customary law is their common law. See Mansingh, supra note 42, at 34 .

73. See id. In the northern tribal region, transportation is rugged and dangerous around the mountainside. See Kluck, supra note 42 , at 72. 
of isolation by continuing their daily struggles regardless of the power plays of the self-interested elites of the local government. ${ }^{74}$

\section{B. Women's Role in Society}

Violence against women, within their own families, is an extension of the subordination of women in the larger society, which is reinforced by religious beliefs, cultural norms, traditional practices, and actual laws in Pakistan. ${ }^{75}$ The women of Pakistan are subjected to the social code of behavior known as purda, which requires that women be safeguarded from unauthorized persons. ${ }^{76}$ When a woman is allowed outdoors, she must be covered completely except for the upper part of her face; and she also must be chaperoned by a male family member. ${ }^{77}$ This social custom scars the women in Pakistan because they develop a deep-seated fear of any interaction with men. ${ }^{78}$

In Pakistan and some other Muslim countries, there is a unique category of criminal conduct committed by women known as "crimes of honor." Honor is a very important aspect of Pakistani culture whereby a man's honor resides in the actions of the women of his family. ${ }^{80}$ These crimes include adultery, freely choosing a marriage partner without the father's permission, or seeking a divorce. ${ }^{81}$ This practice has been deeply rooted in tribal societies for decades. ${ }^{82}$

The woman holds all of the honor for the family and the social order depends upon her maintaining this honor. ${ }^{83}$ In addition, the woman's honor or shame strongly affects the general standing of the tribe within the

74. See TALBOT, supra note 51, at 222.

75. See Anita M. Weiss, Gendered Power Relations: Perpetuation and Renegotiation, in POWER AND CIVIL SOCIETY, supra note 57, at 73. Significant numbers of women are subjected to harassment, violence, rape, and other forms of degradation by spouses and members of society. See U.S. Dep't of State, supra note 19. Traditional social and legal constraints have kept women in a subordinate position within society. See id.

76. See IZZUD-Din Pal, PAKISTAN, Islam \& ECONOMiCs 123 (1999). Purda prohibits social contact between women past the age of puberty and the men who are not part of her family circle. See Kluck, supra note 42 , at 110.

77. See PAL, supra note 76, at 123.

78. See id. at 128.

79. See Roland Pierre Paringaux, Asian Women Exposed to Violence - Pakistan: Cost of a Lie, LE MONDE DIPLOMATIQUE (May 2001), available at http://mondediplo.com/2001/05/ 13pakistan (last visited Jan. 19, 2003).

80. See LibraRY OF CONGRESS, Pakistan: Men, Women and the Division of Space, available at http://lcweb2.loc.gov/frd/cs/pktoc.html (last visited Jan. 19, 2003). Complete chastity among a man's female relations is of the essence; only with good reputation of his mother, daughter, sisters, and wife can a man ensure his honor. See Kluck, supra note 42, at 90.

81. See Amnesty, supra note 10.

82. See Paringaux, supra note 79.

83. See id. 
community. ${ }^{84}$ To ensure that the women do not dishonor their families and tribes, women are restricted in their activities, limited in their mobility, and allowed very limited contact with the opposite sex. ${ }^{85}$

In addition to the common occurrence of gang rape, many women have been killed for a violation of honor ${ }^{86}$ Unfortunately for tribal women, the community socially and morally sanctions such "honor killings." ${ }^{87}$ Further hindering the system is the fact that the State does not generally condemn these activities nor take action against the murderers. ${ }^{88}$ Nevertheless, in 2000 the government declared that there is nothing honorable in this form of murder and that the practice, carried over from ancient tribal customs, is anti-Islamic. ${ }^{89}$

The fact that women are treated less favorably than men is in conflict with the Quran, ${ }^{90}$ which says that men and women should be treated equally. ${ }^{91}$ Furthermore, the Quran reminds men that women have the same status as human beings that men enjoy. ${ }^{92}$ However, the Quran's teachings are in direct conflict with tribal culture, where daughters are often not particularly welcome at birth. ${ }^{93}$

Recent studies referred to rape as an act of deliberate communal humiliation in this region. ${ }^{94}$ Rape is so rampant in Pakistan that every two hours a woman is raped. ${ }^{95}$ Statistics also report that in Punjab, a woman is gang-raped every four days. ${ }^{96}$ However, even with these high rates of occurrence, rape is seldom reported for fear of retaliation. ${ }^{97}$ Even the victim

84. See Kluck, supra note 42, at 107.

85. See id.

86. See U.S. Dep't of State, supra note 19. For the year 2001, more than 800 women were killed by family members in "honor killings." See id.

87. See Farzana Bari \& Saba Gul Khattak, Power Configurations in Public and Private Arenas: The Women's Movement's Response, in POWER AND CIVIL SOCIETY, supra note 57, at 230. "Honor killings" is the cultural tradition of killing those suspected of illicit sexual relations in order to restore tribal or familial honor. See U.S. Dep't of State, supra note 19.

88. See U.S. Dep't of State, supra note 19. Honor killings rarely lead to criminal prosecution or convictions due to the lack of witnesses willing to come forward due to communal pressures. See id.

89. See Amnesty, supra note 10.

90. See Ruane, supra note 15 . The Quran is the primary material source of the word of God as revealed to the Prophet and it is also a source of Islamic guidance. See id.

91. See PAL, supra note 76 , at 132.

92. See id.

93. See id.

94. See AKBAR S. AHMED, JinNAH, PAKISTAN \& ISLAMIC IdENTITY 228 (1997).

95. See Sheikh, supra note 1. The Human Rights Commission of Pakistan (HRCP) estimates that at least eight women are reported to be raped every day; and more than two-thirds of them are victims of gang rape. See Mona Eltahawy, Rape as Punishment WASH. POST, July 28,2002 , at B7.

96. See Sheikh, supra note 1. See also U.S. Dep't of State, supra note 19.

97. See id. In 2001, HRCP reported that in the populous province of Punjab, a woman is raped every six hours and a woman gang-raped every fourth day, yet only 321 rape cases were reported last year. See ABC NEWS, Pakistan Supreme Court Orders Probe Of Rape Order, July 4, 2002, at http://www.abc.net.au/news/2002/07/item20020704080758_1.htm (last visited Jan. 19, 2003). HRCP estimates that only one-third of all rapes are actually reported to 
of the gang rape discussed did not register a complaint with the local police force until eight days later. ${ }^{98}$

In addition to rape, honor killings frequently occur in Pakistan. ${ }^{99}$ The killings are on the rise because the murderers in honor killings are rarely punished. ${ }^{100}$ Furthermore, as the women in Pakistan gain knowledge of their rights and begin to assert them, the rate of honor killings also increases. ${ }^{101}$

\section{National Identity}

The lack of a national identity has a causal connection with Pakistan's state of lawlessness. ${ }^{102}$ Within the territorial boundaries, there are several ethnic and tribal areas that maintain their own autonomy. ${ }^{103}$ Therefore, Pakistan has a hodgepodge of governing laws gathered from old British laws, Islam laws, state and tribal laws. ${ }^{104}$ In the rural areas where transportation and communication is poor, the tribes are independent and the villages tend to be isolated even from neighboring tribes. ${ }^{105}$ When the tribes live by the law of their own tribe without the social interaction from other tribes, the traditional social customs dominate their life. ${ }^{106}$

The notion of national identity or loyalty has little value to the Pakistani citizens. ${ }^{107}$ Ethnic, regional, caste, and family loyalties factor more in society than the national loyalty. ${ }^{108}$ An individual's loyalties are defined in terms of family, local leaders, clan or tribe, and caste. ${ }^{109}$ The people of Pakistan have always remained distant from the political system and they have been unable to understand a Constitutional theory or relate to the idea of a consensual plurality or national identity. ${ }^{110}$ On the contrary, the citizens have continued to follow the local tribal leaders whom they trust. ${ }^{111}$

the police. See U.S. Dep't of State, supra note 19.

98. See Sheikh, supra note 1.

99. See WSC Speaks at UN on Kalabagh Dam and the Plight of Women in Sindh, THE SindH Perchar (World Sindh Congress, Sindh), Dec. 2000, at 1, 9 [hereinafter THE SiNDH PERCHAR].

100. See id.

101. See id.

102. See AHMED, supra note 94 , at 171.

103. See id. Pakistan is comprised of distinct diverse cultures each intensely committed to its unique heritage and way of life. See Kluck, supra note 42, at 80.

104. See AHMED, supra note 94, at 217.

105. See id. at 191.

106. See id. at 191-92.

107. See Kluck, supra note 42 , at 78.

108. See id. at 67.

109. See id. at 78.

110. See Lawrence Ziring, Government and Politics, in PAKISTAN: A COUNTRY STUDY, supra note 42, at 186 .

111. See id. 
Without a national identity, Pakistan has created a weak and shaky political and social structure. ${ }^{112}$ As a result, society has disintegrated into a collection of individual and tribes where the lawlessness further reinforces the tribal loyalties. ${ }^{113}$ The tribes live and socialize amongst themselves and are only concerned with the political and economic benefits for themselves. ${ }^{114}$

\section{Caste Systems}

A caste system exists in Pakistan to distinguish the different levels of society. ${ }^{115}$ The structure of society in the provinces of Pakistan are casteridden and tribal-feudal, ${ }^{116}$ with the upper castes having large holdings of land while the lower castes consist of peasants who are treated as slaves. ${ }^{17}$ The caste's levels are based upon the specialized occupations that one holds. ${ }^{118}$ Ideally, the multi-level caste systems are self-sufficient in providing the community with the needed goods and services thereby alienating them from other tribal interaction. ${ }^{119}$

The landed-elite were favored during the pre-Pakistan days when Britain ruled the region whereby an exchange was made for the British to meet the wants and needs of the Punjab tribal landlords who reciprocated by maintaining the law and order in the rural areas. ${ }^{120}$ With agriculture being the main industry in Pakistan's economy, landlords are prominent figures in society because they wield both political and economic power to either grant favors or render sanctions against others. ${ }^{121}$ When Pakistan was formed, the State's independence did not change this social and cultural atmosphere. ${ }^{122}$ Although the lower castes are guaranteed equal rights through the Constitution, it is clear they are being denied economic and political

112. See AHMED, supra note 94, at 218.

113. See id. at 247.

114. See id.

115. See Kluck, supra note 42 , at 80 . There are a variety of castes, based upon occupational groups. See id. The most significant social marker is the distinction based upon the caste which one belongs. See id. at 83.

116. See Kennedy, supra note 44 , at 28 . Pakistan's rural structure contains feudalist elements where the big landlords fulfill the role of the feudal lords, controlling the economic, political, and social order. See id. Village caste systems include landowners, farmers, religious leaders, and craftsmen. See Kluck, supra note 42, at 105.

117. See GHUlam Kibria, A ShatTEREd DREAM: Understanding Pakistan's UNDERDEVELOPMENT 226 (1999).

118. See Kluck, supra note 42 , at 83 . Village caste systems varied from the higher landowner farmers to the lower end of the occupations hierarchy containing the craftsmen such as cobblers, sweepers and garbage collectors. See id. at 105.

119. See id.

120. See id. at 83. Landlords presided over the tribal areas with little concern for any outside interference. See id. at 84.

121. See id. at 68.

122. See Kluck, supra note 42 , at 83. 
privileges. ${ }^{123}$ Furthermore, the landlords defied the courts and provincial law by holding illegal tribal jirgas to settle feuds, award fines, and even sentence people to the death penalty. ${ }^{124}$

Similar to the discrimination that the women in these tribal regions endure, the lower castes are also subjected to discrimination. ${ }^{125}$ The higher caste members generally are segregated from the lower castes and typically cannot share food with the lower castes nor can they marry someone from the lower castes. ${ }^{126}$ Furthermore, the inequality in the distribution of income adversely affects crime prevention and criminal justice systems. ${ }^{127}$ The wealthy and influential citizens benefit from the police protection, while the less fortunate victims and witnesses end up facing retaliation for reporting the offense. ${ }^{128}$ Consequently, there is a miscarriage of justice when there is a failure to convict the guilty among the rich and powerful higher castes; while the lower castes are wrongfully convicted. ${ }^{129}$ Some citizens petitioned the courts to look into the wrongdoings of the police, but even the court ordered inquiries result in very few trials and so far no convictions have been obtained against any police officers. ${ }^{130}$

\section{E. Economic Effect}

Unfortunately, Pakistan has not maintained the economic growth that its neighboring countries have sustained. ${ }^{131}$ Countries without the law and order

123. See AHMED, supra note 94, at 171. In 1947, in a speech, Muhammad Ali Jinnah, the founder of Pakistan, stated that:

[If you change your past and work together in a spirit that every one of you, no matter to what community he belongs, no matter what relations he had with you in the past, no matter what is his colour, [sic] caste or creed, is first, second and last a citizen of this State with equal rights, privileges and obligations, there will be no end to the progress you will make.] .... [We are starting in the days when there is no discrimination, no distinction between one community and another, no discrimination between one caste or creed and another. We are starting with this fundamental principle that we are all citizens and equal citizens of one State.]

See id. at 174-75. See also Jinnah's Presidential Address, Aug. 11, 1947, available at http://www.sdp.org.pk/Quaid.htm (last visited Feb. 26, 2003).

124. See U.S. Dep't of State, supra note 19.

125. See AHMED, supra note 94 , at 51 .

126. See id.

127. See NADEEM, supra note 3, at 301 . Pakistan is an extremely impoverished country with great extremes in the distribution of wealth. See U.S. Dep't of State, supra note 19.

128. See NADEEM, supra note 3, at 302 . Members of the police themselves have committed numerous serious human rights violations. See U.S. Dep't of State, supra note 19.

129. See Nadeem, supra note 3, at 302.

130. See U.S. Dep't of State, supra note 19.

131. See Shahid Javed Burki, Politics of Power and Its Economic Imperatives: Pakistan 1947 - 99, in POWER AND CIVIL SOCIETY, supra note 57, at 163. See also WORLD BANK, 2002 PAKISTAN COUNTRY BRIEF: Pakistan's Development Progress, available at http://www.world bank.org.pk/sar/sa.nsf/083c4661ad49652f852567d7005 d85b8/e446d9087f72838e85256b02006 
problems that plague Pakistan, generally benefit from having economic stability and economic growth. ${ }^{132}$ Because of its state of lawlessness, Pakistan has suffered the effects of the industrialists fleeing the region. ${ }^{133}$

Also, Pakistan is somewhat disadvantaged where foreign investment is concerned. ${ }^{134}$ Economists believe that foreign investment is closely related to domestic investment. ${ }^{135}$ Many of the more advantaged members of society are merely concerned with their wants and needs. ${ }^{136}$ As a result, foreign investors do not build business relationships with the local entrepreneurs. ${ }^{137}$ Many of the impoverished are in the rural areas where they are plagued with problems. ${ }^{138}$ The Pakistan government has not made sufficient efforts to provide any social services to the tribal people. ${ }^{139}$ Thus, even though millions are being spent on nuclear warfare, most of society remains in poverty. ${ }^{140}$ The amount of funding that is allocated for criminal justice administration is extremely inadequate. ${ }^{141}$ Nonetheless, it is reported that Pakistan spends seventy percent $(70 \%)$ of its budget on defense-related projects. ${ }^{142}$

Additionally, the Pakistani economy ultimately is disadvantaged because they have excluded women from the social and political process. ${ }^{143}$ Modern economic advisers see the need for women to participate in the economic sector in order to promote development of the country. ${ }^{144}$ Unfortunately, the traditional cultural norm is that women should not be allowed out of the house, much less employed. ${ }^{145}$

cbff4 (last visited Jan. 19, 2003). Pakistan still lags behind countries with comparable per capita income in most social indicators. See id.

132. See NADEEM, supra note 3, at 300 . Economic development has been tied to political instability and lawlessness. See id. at 137 . In the late 1960s, the breakdown of law and order led to a fall of annual growth rate from earlier in the 1960s average year's rate of 5.5 percent to 1.4 percent. See id. at 138 . "[C]onditions of law and order must have direct and significant bearing on the peace and pattern of economic development of a country." Id. at 1 .

133. See id. at 162.

134. See id. at 176.

135. See id.

136. See NADEEM, supra note 3, at 177.

137. See id.

138. See AHMED, supra note 94 , at 218 . The lower caste members are generally the tenants who do not own land and are often treated as slaves of the feudal landlords that own vast estates. See id.

139. See id. Reforms by the government have had little effect on reducing inefficiency and corruption in some levels of government. See U.S. Dep't of State, supra note 19.

140. See Dr. Rubina N. Shaikh, Briefing on Human Rights Situation in Sindh, THE SINDH Perchar (World Sindh Congress, Sindh) Dec. 2000, at 7.

141. See NADEEM, supra note 3 , at 56.

142. See id.

143. See PAL, supra note 76 , at 121.

144. See id.

145. See id. 


\section{ROLE OF TRIBAL COUNCILS}

In some rural areas of Pakistan, a tribal judiciary forum traditionally deals with crimes of dignity and punishes the offenders outside of Pakistani law. ${ }^{146}$ Their role is to bring reconciliation between the conflicting parties, based upon evidence and arguments presented. ${ }^{147}$ During this process, the respected elder members of the jirga are consulted frequently. ${ }^{148}$

Similar to the Western tort law system, the tribal council's focus is on reconciliation and conflict resolution; however, it is not focused on punishment. ${ }^{149}$ Also, tribal law is not necessarily aimed at finding out the truth. $^{150}$ In the federal court system, often the individual takes an oath, and then fearing that the truth will come out and he will consequently lose the case, he proceeds to lie in his testimony. ${ }^{151}$ In contrast, the panchayat system allows the individual to give a true account because there is trust among the locals as opposed to the federal justices who are mistrusted. ${ }^{152}$ With regard to reconciliation, the panchayat system has the objective of ending the hostility peacefully. ${ }^{153}$ In a trial court, the hostility remains after the verdict and sentence are imposed. ${ }^{154}$

The jirgas often resolve land conflicts between two warring factions, water disputes, inheritance disputes, honor breaches, and internal and external tribal killings. ${ }^{155}$ Many cases have been reported where the jirgas have sentenced the tribes to pay for crimes its members have committed such as kidnapping or theft. ${ }^{156}$ Some wrongful death claims have also been settled before a jirga. ${ }^{157}$ The tribal juries have been known to impose cruel and degrading punishments; and although they rarely impose the death penalty, they have rendered the death sentence in some honor cases. ${ }^{158}$

146. See Associated Press, supra note 12.

147. See Amnesty, supra note 10.

148. See id.

149. See id. Justice is understood not in terms of punishment thereby leading to remorse and rehabilitation, but strictly in terms of conciliation to restore the balance that was disturbed by the offense. See id.

150. See id.

151. See id.

152. See Amnesty, supra note 10.

153. See id.

154. See id. In January 2000 , in the Pakistan province of Baluchistan, a Chief Justice of the Baluchistan High Court was murdered in a personal vendetta arising out of a court matter. See U.S. Dep't of State, supra note 19.

155. See Amnesty, supra note 10.

156. See id. Tribal juries are reported to have imposed fines for those breaking the peace. See id.

157. See id.

158. See id. In the remote areas outside of the jurisdiction of federal political agents, the jirgas often levy harsher punishments including flogging or death by stoning. See U.S. Dep't of State, supra note 19. 
It appears that the tribal council form of justice increased in the past few years. ${ }^{159}$ The $\mathrm{HRCP}^{160}$ filed a report in 2001 with three full pages dedicated to a discussion of jirga rule. ${ }^{161}$ There also are regular adjudication days that are widely known and attended by many individuals. ${ }^{162}$

Generally, the State has been supportive toward the actions of the tribal councils. ${ }^{163}$ When actions have violated human rights or caused severe physical harm, the council members have not been prosecuted by the State. ${ }^{164}$ However, after the gang-rape incident, the government urged the local police to investigate and arrest those that violated the law. ${ }^{165}$

Many human rights organizations and others would like to see these tribal councils eliminated. ${ }^{166}$ It is clear that the jirgas affect the human rights of the citizens. ${ }^{167}$ However, the State appears to acquiesce to these frequent practices. ${ }^{168}$ Although the Pakistan Constitution outlaws the panchayats, Pakistan is ultimately responsible for their actions. ${ }^{169}$ The government has failed to use due diligence to prevent the abuses and provide adequate justice to the victims. ${ }^{170}$

The councils consist of non-elected bureaucrats who usually come from the prominent landholding class. ${ }^{171}$ Many tribal leaders are actually parliamentary members themselves or have family links with the government administration. ${ }^{172}$ However, there is no specialized training provided to the tribal councils who are making judgments. ${ }^{173}$

159. See Amnesty, supra note 10.

160. See HRCP, supra note 47.

161. See id. In 1999, the annual report did not even discuss the jirgas but in 2000, the report devoted a half page discussing the tribal councils' efforts as a judicial tribunal. See id.

162. See id.

163. See id.

164. See id.

165. See Associated Press, supra note 12. Punjab government's Law Minister visited the village and promised a full investigation. See id. Punjab's Deputy Inspector General of Police informed the village that the top officer at the local police station had been suspended in response to their failure to investigate the incident. See id. Ultimately, the ATC found the four rapists and two council members guilty or rape and sentenced them to death. See Kamila Shamsie, Child Abuse in Belgium "Shocks the Nation": So Why is Gang Rape in Pakistan "A Cultural Issue," in THE GUARDIAN (Sept. 6, 2002), available at 2002 WL 26657006.

166. See Sheikh, supra note 1.

167. See Amnesty, supra note 10.

168. See id.

169. See The Constitution of the Islamic Republic of Pakistan, art. 175 (1) \& (2), available at http://www.pakistani.org/pakistan/constitution/ (last visited Jan. 19, 2002) [hereinafter Pak. Const.]. Specifically, stated in the System of Sardari (Abolition) Act of 1976 "The system of Sardar, prevalent in certain parts of Pakistan, is the worst remnant of the oppressive feudal and tribal system which, being derogatory to human dignity and freedom, is repugnant to the spirit of democracy and equality . . . in the Constitution of the Islamic Republic of Pakistan." Amnesty, supra note 10.

170. See id.

171. See Kennedy, supra note 44, at 28.

172. See Amnesty, supra note 10.

173. See id. 
Some courts refer civil disputes to the tribal councils. ${ }^{174}$ Although state officials avoid recognizing the tribal justice system as a legitimate judiciary, the officials ask for advice on how to handle complicated cases. ${ }^{175}$ However, those proceedings related to criminal actions, including murder, assault, and land trespasses, are to be tried by the constitutional court system. ${ }^{176}$ Yet, in the tribal regions, the government has little or no authority over citizens, rendering the federal court system somewhat useless. ${ }^{177}$

Primarily, laws enforced in the tribal courts have been handed down from one generation to the next. ${ }^{178}$ Rural tribal villages have persisted effectively for centuries without laws but have maintained a code of informal standards of social conduct. ${ }^{179}$ Furthermore, the informal set of codes that the tribes follow may have a more powerful hold on behavior of its members than the State's formal laws. ${ }^{180}$ The tribal code has been enforced through the conscience of the tribal members and also by the tribal councils sanctions such as ostracision. ${ }^{181}$ Typically, the social pressure from the tribal community requires that the verdicts be carried out. ${ }^{182}$

The tribal jury may consult with tribal elders or schoolteachers when determining decisions. ${ }^{183}$ These advisers or counselors feel honored when consulted and their opinions are respected and highly valued. ${ }^{184}$ The proceedings continue through a mediation-type process until a compromise is met. ${ }^{185}$ There is no appellate procedure; thus, the Supreme Court cannot hear an appeal on a jirga ruling because they do not recognize the tribunal. ${ }^{186}$

\section{CONFLICTS WITH PAKISTANI LAW}

Pakistan is a country with Muslim ideology as the rule of law. ${ }^{187}$ According to some modern Muslim leaders, a country cannot be an Islamic state when there is a feeling of insecurity as a result of lawmakers breaking the

174. See id.

175. See id. Tribal council leaders have confirmed that members of the judiciary had approached them for advice on cases that have an impact on the tribes. See id.

176. See id.

177. See Eugene K. Keefe, National Security, in PAKISTAN: A COUNTRY STUdY, supra note 42 , at 304 .

178. See SCHAPERA, supra note 34, at 69.

179. See NADEEM, supra note 3 , at 15.

180. See id.

181. See id.

182. See Amnesty, supra note 10.

183. See id.

184. See id.

185. See id.

186. See id.

187. See LiBraRY OF CONGRESS, Pakistan: Role of Islam, available at http://lcweb2.loc. gov/frd/cs/pktoc.html (last visited Jan. 19, 2003). Efforts to apply Quranic law in a modern political contest have had a direct impact on Pakistan's political history. See id. The official name of the State is the Islamic Republic of Pakistan. See Pakistan Basic Facts, supra note 19. 
law. ${ }^{188}$ Subsequently, the citizens fear the police, who are there to protect and enforce the law, more than fearing those that break the law. ${ }^{189}$

The Pakistan Constitution ${ }^{190}$ has an Equal Protection section that prohibits discrimination on account of religion, race, caste, color, or creed. ${ }^{191}$ Although fundamental rights were given through the Pakistan Constitution, they are still subject to law. ${ }^{192}$ Consequently, if the laws in question are in conflict with public morality or public order, it is likely that these fundamental rights will be ignored. ${ }^{193}$

Although the panchayat involved in the gang rape of the Gujjar woman rendered the sanction, rape is a criminal offense in Pakistan. ${ }^{194}$ However, this is not an isolated event where the panchayat has sexually harassed a party to the dispute. ${ }^{195}$ It also has been reported that a Punjab village council ordered the wife of a man who was convicted of rape to be raped by the victim's husband. ${ }^{196}$ The tribal community socially and morally accepted these sanctions as punishment. ${ }^{197}$ Furthermore, the State failed to take any action against the tribal councils for their human rights violations. ${ }^{198}$

Other violations of human rights committed by the tribal councils include the trading or killing of women as a means of retribution to settle the scores between conflicting parties, ${ }^{199}$ and the handing over of women as a form

188. See KIBRA, supra note 117 , at 224-25.

189. See id.

190. See Pak. Const., supra note 169.

191. See id. Article 25 states that:

All citizens are equal before law and are entitled to equal protection of law.

There shall be no discrimination on the basis of sex alone.

Nothing in this Article shall prevent the State from making any special provision for the protection of women and children.

Id. See also PAKISTAN GOVERNMENT, Responsibilities Covering Human Rights, available at http://www.infopak.gov.pk (last visited Jan. 20, 2003.)

192. See Farooq Hassan, Religious Liberty in Pakistan: Law, Reality and Perception, 2002 BYU L. REV. 283, 288 (2002).

193. See id.

194. See Asifa Quraishi, Her Honor: An Islamic Critique of the Rape Laws of Pakistan From A Woman-Sensitive Perspective, 18 MiCH. J. INT'L L. 287, 288 (1997).

195. See Tribal System on Trial, supra note 11.

196. See Bari \& Khattak, supra note 87 , at 230 . A village council near Mithankot in the province of Punjab, ordered a wife of a man convicted of rape to be raped by the victim's husband. See id. Similar to the gang-rape incident, several tribal elders watched as the sentence was carried out without intervening. See id.

197. See id. The community also sanctions the death penalty. See id. A tribal council in Hyderabad imposed the death penalty on a newly married couple because they had committed adultery by having sexual intercourse prior to their marriage. See id. It is reported that approximately 15,000 people watched as the executions were rendered. See Bari \& Khattak, supra note 87 , at 230 .

198. See id.

199. See id. There is a custom in which teenage girls are bargained away to settle feuds. See Ralph Joseph, Musharraf Targets Abuse of Pakistani Women, WASH. TIMES, Aug. 16, 2002, available at http://www.washtimes.com/world/20020816-68542664.htm (last visited Jan. $20,2003)$. 
of settlement of a dispute. ${ }^{200}$ In this often-repeated act, the unfortunate women are not consulted, nor do they give their consent, yet they are turned over to live in a hostile environment. ${ }^{201}$ Disputes involving honor result in the exchange of women. ${ }^{202}$ For purposes of compensation payments, the standard amount of compensation for the murder of a man is rs $200,000^{203}$ while the murder of a woman is rs $400,000 .^{204}$ However, when murder has occurred, the jirga generally resolves the dispute without having the local authorities involved. ${ }^{205}$

One jirga decided that two very young girls from the murderer's side of the family would be turned over to the family of the victim. ${ }^{206}$ Unfortunately for females, the handing over of women is considered to be the best way to cool tempers and heal the conflict by bringing the families together through marriage. ${ }^{207}$

Before 1979, the Pakistan Penal Code ${ }^{208}$ regulated the criminal offense of rape. ${ }^{209}$ However, after a military coup brought General $\mathrm{Zia}^{210}$ to power with a goal to Islamisize Pakistan, he enacted the Zina Ordinance, ${ }^{211}$ which repealed the crime of rape under the Pakistan Penal Code. ${ }^{212}$ The Zina Ordinance regulated sexual intercourse between two individuals who were not married, whether it was consensual or not. ${ }^{213}$ If the intercourse was

200. See Amnesty, supra note 10.

201. See id.

202. See id. However, land or water disputes usually will involve compensation in the form of money, land, or water. See id.

203. See Pakistan Basic Facts, supra note 19. The amount represents 200,000 rupees, which is the Pakistan form of money. See id.

204. See Amnesty, supra note 10. The higher award for women is based on the fact that women are not involved in the dispute and therefore are innocent parties of the dispute. See id. However, some tribal councils have taken into consideration the economic standing of the perpetrator and have lowered the imposed rates accordingly if the culprit is poor. See id.

205. See id.

206. See id. The eleven year old daughter of one of the accused was made to marry the forty-six year old father of the victim while a six-year old daughter of an accused was forced to marry the eight year old brother of the victim. See id.

207. See Amnesty, supra note 10.

208. See Library of CONGRess, Pakistan: Courts and Criminal Procedure, available at http://lweb2.loc.gov/frd/cs/pktoc.htmllpk0108 (last visited Jan. 20, 2003). Pakistan has an extensive penal code, based on the Indian Penal Code of 1860. See id. The Pakistan Penal Code contains provisions for punishment of crimes against the state or against public tranquility. See id. The majority of the code deals with crimes against persons and properties such as robbery and misappropriation of property. See id.

209. See Julie Dror Chadbourne, Never Wear Your Shoes After Midnight: Legal Trends Under the Pakistan Zina Ordinance, 17 WIS. INT'L L.J. 179, 184 (1999).

210. See Baxter, supra note 31, at 1. General Zia overthrew the government of Pakistan in 1977. See id.

211. See Lawyers for Human Rights and Legal Aid, defining Zina Ordinance P.L.D. Cent. Statutes 51 (1979), available at http://www.lhrla.sdnpk.org/hudood.html (last visited Jan. 20, 2003).

212. See Quraishi, supra note 194, at 288; see also Chadbourne, supra note 209, at 183-84.

213. See Quraishi, supra note 194, at 289; see also Chadbourne, supra note 209, at 191. 
consensual, the crime of $z i n a^{214}$ was committed; and if the intercourse was not consensual, the crime was zina-bil-jabr. ${ }^{215}$ In addition, the Zina Ordinance sets forth the evidentiary standards and the punishments available for the criminal offense of rape. ${ }^{216}$

The punishment for rape, if convicted, is the death penalty; however, there have been no executions carried out under this law. ${ }^{217}$ Despite the punishments available for the crime of rape, it is so widespread that rape has been decriminalized. ${ }^{218}$ Furthermore, the burden of proof in a rape claim falls upon the victim. ${ }^{219}$ This is extremely hard to prove because the Law of Evidence provides that the testimony of a woman is equated to that of two

214. See Quraishi, supra note 194, citing Zina Ordinance $\$ \S 4,5$ P.L.D. 1979 Cent. Statutes at 52 .

Zina is liable to hadd [punishment] if--

(a) it is committed by a man who is an adult and is not insane with a woman to whom he is not, and does not suspect himself to be married; or

(b) it is committed by a woman who is an adult and is not insane with a man to whom she is not, and does not suspect herself to be married.

Quraishi, supra note 194, at 290.

215. See id. citing Zina Ordinance \$6 P.L.D. 1979 Cent. Statutes, at 52.

A person is said to commit zina-bil-jabr if he or she has sexual intercourse with a woman or man, as the case may be, to whom he or she is not validly married, in any of the following circumstances, namely-

(a) against the will of the victim,

(b) without the consent of the victim,

(c) with the consent of the victim, when the consent has been obtained by putting the victim in fear of death or of hurt, or

(d) with the consent of the victim, when the offender knows that the offender is not validly married to the victim and that the consent is given because the victim believes that the offender is another person to whom the victim is or believes herself or himself to be validly married.

Id. at 289. Zina-bil-jabr means zina with force. See id. at 288. See also Chadbourne, supra note 209 , at $191-92$.

216. See Quraishi, supra note 194, citing Zina Ordinance § 8 P.L.D. 1979 Cent. Statutes at 53. The Zina Ordinance specifies the evidence required to prove both zina and zina-bil-jabr.

Proof of zina or zina-bil-jabr liable to hadd shall be in one of the following forms, namely-

(a) the accused makes before a Court of competent jurisdiction a confession of the commission of the offence; or

(b) at least four Muslim adult male witnesses, about whom the Court is satisfied, having regard to the requirements of tazkiyah al-shuhood [credibility of witnesses], that they are truthful persons and abstain from major sins (kabair), give evidence as eyewitnesses of the act of penetration necessary to the offence [sic].

Quraishi, supra note 194, at 290; see also Chadbourne, supra note 209, at 184 . The evidentiary standards for successful prosecution under the Zina Ordinance require proof of sexual activity by witnessing the sexual intercourse or the accused must confess in court. See Quraishi, supra note 194 , at 295.

217. See U.S. Dep't of State, supra note 19.

218. See Paringaux, supra note 79.

219. See id. 
men. ${ }^{220}$ In addition, claims of rape can be proven by the rapist admitting to the attack after the woman has filed a First Information Report (FIR) ${ }^{221}$ or by having four male witnesses of good standing in the community to verify the claim. $^{222}$ Although rape is hard to prove, if successfully proven, possible punishments include death by hanging. ${ }^{23}$

The 1973 Constitution ensured full participation of women in all walks of life and declared that discrimination on the basis of sex or creed is illegal. ${ }^{224}$ Yet, with the aforementioned rape statistics, ${ }^{225}$ it is clear that women are not being protected and are further discriminated against with the code of honor. ${ }^{226}$ The legislature enacted to protect women are constantly being breached, and seldom observed as law. ${ }^{227}$ Women fear that if they do report being raped, they will be subjected to prosecution under the Zina Ordinance if they are unable to prove the offense. 228

The State, as well as the police department, has a responsibility to provide protection to life, property and honor of the people and also to ensure justice to all persons. ${ }^{229}$ However, the antiquated Act presupposes a society without a governing agreement or Constitution and provides for authority with no recognition of fundamental rights and no accountability. ${ }^{230}$ The Act also did not allow for any provisions of a national police force organized at the national level. ${ }^{231}$ Additionally, as a result of the martial law that was enacted when the military came to power, the policing is done in a paramilitary fashion. ${ }^{232}$

The police authority in Pakistan is typical of the roles that police officers across the world perform: executing orders and warrants; ensuring public order; preventing crimes; and apprehending criminals. ${ }^{233}$ It is the police who

220. See TALBOT, supra note 51, at 211. The Law of Evidence of 1984 laid down the principle that the evidence of two women was only equal to that of one man. See id.

221. See Chadbourne, supra note 209, at 194. First Information Report (FIR) is also known as a police report. See id. After the FIR is filed by the complainant, the police may then arrest an individual based on the report. See U.S. Dep't of State, supra note 19.

222. See TALBOT, supra note 51, at 211.

223. See KEEFE, supra note 177 , at 299 . In 1979 , a new legal code from the Islamization of Pakistani Society set forth the new punishments for sexual offenses. See id.

224. See PAL, supra note 76, at 135.

225. See Eltahawy, supra note 95.

226. See id.

227. See Kluck, supra note 42, at 112. When asked about the rape statistics in Punjab, it was one Punjab police officer's opinion that the registered rapes were usually instances of adultery and not sexual intercourse by force. See Weiss, supra note 75 , at 73.

228. See id. at 72.

229. See Sheikh, supra note 1.

230. See NADEEM, supra note 3 , at 214.

231. See KEEFE, supra note 177, at 294.

232. See NADEEM, supra note 3, at 263.

233. See LIBRARY OFCONGRESS, Pakistan - Intermal Security: Role and Structure of the Security Forces, available at http://lcweb2.loc.gov/frd/cs/pktoc.html\#pk0108 (last visited Nov. 19, 2002). 
are responsible for the prevention and detection of crime, thereby protecting the life and property of the public and ensuring peace in the community. ${ }^{234}$ Yet, the police in Pakistan, despite the large population they govern, are limited in resources due to lack of funding. ${ }^{235}$ They fail to provide security to law-abiding citizens and appear to be indifferent to the jirgas who commit atrocious human rights violations. ${ }^{236}$

As a result of the current law and order situation, there is an element of fear that keeps the citizens from creating a relationship with the police. ${ }^{237}$ Despite the role the police fulfill in society, the public perceives them as cruel and corrupt. ${ }^{238}$ The public confidence in the rule of law has been eliminated causing most crimes to never be reported; and those crimes that are reported to the police are not usually ever registered ${ }^{239}$ for an investigation. ${ }^{240}$ Additionally, it is reported that many bribes are made to police officials to buy the culprits release. ${ }^{241}$ The citizens feel socially and politically oppressed by the police and therefore do not see the fulfillment of its role as protector and preserver of peace. ${ }^{242}$

Persons who commit honor killings are not seen as criminals, but merely the person rendering the punishment to the wrongdoer. ${ }^{243}$ Yet, Pakistani and international law considers this to be murder. ${ }^{244}$ However, the law is scarcely applied in this culture where honor is of utmost importance and consequently the killings continue. ${ }^{245}$ When the courts rule in favor of the victim, community hostility and violence are carried out against the victims. ${ }^{246}$ The

234. See NADEEM, supra note 3 , at 214-15.

235. See id. at 216 . Police training is inadequate by only requiring six months of training. See U.S. Dep't of State, supra note 19. Developed countries show a higher allocation of policemen per number of citizen than Pakistan. See NADEEM, supra note 3, at 263. Punjab has 140 policemen for every 825 citizens; and England has 140 police officers for every 427 citizens and Japan has 140 officers for 555 citizens. See id.

236. See Amnesty, supra note 10. Local police do not take any action to stop the criminal intimidation by the jirga. See id. An example being where a woman married a male without her father's permission and the tribe was intending to kill the woman, the police failed to ensure the woman's physical safety or to secure her right to have a say in her marriage. See id.

237. See NADEEM, supra note 3 , at 224.

238. See id. at 214.

239. See U.S. Dep't of State, supra note 19. The First Incident Report is a complaint that is filed with the local police that registers the allegation. See id.

240. See NADEEM, supra note 3, at 115.

241. See KEEFE, supra note 177, at 298. "A constable who fails to make at least twice his official wages in bribes gets fired for laziness." See id. In the rural tribal areas, some culprits are either powerful and well-connected or simply manage to bribe their way out of trouble. See Amnesty, supra note 10.

242. See NADEEM, supra note 3, at 219.

243. See Paringaux, supra note 79.

244. See id. The Pakistani government has criticized the practice of "honor killings" but they have failed to take any corrective actions to end this practice, so the killings continue. See id.

245. See U.S. Dep't of State, supra note 19.

246. See Paringaux, supra note 79. 
Gujjar woman, previously discussed, and her family planned to move out of their village for fear of reprisal after they received threats from her attackers' clan. ${ }^{247}$ Judges who render the verdicts are also potential victims and may receive threats of being attacked. ${ }^{248}$

The Ombudsman office ${ }^{249}$ was established by the Constitution to ensure that no wrongs are done to Pakistani citizens. ${ }^{250}$ The Ombudsman has the authority to take remedial action such as rendering compensation to victims of an administrative abuse of authority. ${ }^{251}$ Government officials, including President Musharraf, ${ }^{252}$ the Ombudsman, and the Minister of Women's Affairs, gave the Gujjar woman who was gang-raped an award of rs500,000 to compensate her for her horrible ordeal at the hands of the local panchayat. ${ }^{253}$ In addition, the federal government stepped in when a woman was sexually/genitally mutilated by her husband by providing medical treatment from abroad at the State's expense. ${ }^{254}$ Unfortunately, these actions are not sufficient to overcome the traditional norms that have been in practiced by the rural tribes for decades. ${ }^{255}$

Aside from Pakistani law, the country has adopted the United Nations Convention for Elimination of Discrimination Against Women (CEDAW). ${ }^{256}$ CEDAW defines discrimination against women as:

[A]ny distinction, exclusion or restriction made on the basis of sex which has the effect or purpose of impairing or nullifying the recognition, enjoyment or exercise by women,

247. See Zahid Hussain, Six To Be Hanged For Pakistan Gang Rape, TIMES (London), Sept. 2, 2002, available at 2002 WL 4236993. The police have increased security at the home of the gang-rape victim because of the threats against the woman as well as those who support her. See CRI, supra note 2.

248. See U.S. Dep't of State, supra note 19. A Chief Justice was killed in a personal vendetta arising out of a court case. See id.

249. See LIBRARY OF CONGRESS, Pakistan: Judiciary, available at http://lcweb2.loc.gov/frd/cs/pktoc.html\#pk0108 (last visited Nov. 19, 2002). The Ombudsman office was set up under the judiciary to create a system fro enforcing administrative accountability, through investigating and rectifying any injustice done to a person through maladministration by a federal or government official. See id. Excluded from their jurisdiction are those matters relating to foreign affairs, national defense, and the military. See id. Basically, the institution was designed to help curb a public servant's misuse of discretionary powers. See id.

250. See U.S. Dep't of State, supra note 19.

251. See id.

252. See Pakistan Basic Facts, supra note 19.

253. See Zahra, supra note 7.

254. See Bari \& Khattak, supra note 87 , at 225.

255. See Amnesty, supra note 10.

256. See Convention on the Elimination of All Forms of Discrimination Against Women, Jan. 22, 1980, 19 I.L.M. 33 (entered into force Sept. 3, 1981), available at http://www.unhchr.ch/html/menu3/b/e1cedaw.htm (last visited Feb. 3, 2003) [hereinafter CEDAW]. As a signatory to the CEDAW, the States agree to abolish discriminatory laws and to take all appropriate steps to promote essential human rights freedom for women. See id. 
irrespective of their marital status, on a basis of equality of men and women, of human rights and fundamental freedoms in the political, economic, social, cultural, civil or any other field. ${ }^{257}$

Although Pakistan became a signatory to CEDAW on March $12,1996,{ }^{258}$ the government fails to abide by this United Nations Conventions and other international human rights conventions. ${ }^{259}$

\section{OfFicial PaKistani Justice SyStem}

The judicial system of Pakistan consists of a Supreme Court, provincial high courts, and lower courts that exercise jurisdiction over civil and criminal matters. ${ }^{260}$ As previously mentioned, some criminal matters are heard in the ATC in order to expedite the process. ${ }^{261}$ There is also the Shariat Court ${ }^{262}$ that determines whether a civil law is aligned with the law of Islam. ${ }^{263}$ The Shariat Courts were set up at the provincial level to review consistency with Islam

257. CEDAW, supra note 256 , art. 1 , part 1 .

258. See id. at Status of Ratification. Other parties to the CEDAW are: Afghanistan, Albania, Algeria, Andorra, Angola, Antigua and Barbuda, Argentina, Armenia, Australia, Austria, Azerbaijan, Bahamas, Bangladesh, Barbados, Belarus, Belgium, Belize, Benin, Bhutan, Bolivia, Bosnia and Herzegovina, Botswana, Brazil, Bulgaria, Burkina Faso, Burundi, Cambodia, Cameroon, Canada, Cape Verde, Central African Republic, Chad, Chile, China, Colombia, Comoros, Congo, Costa Rica, Cote d'Ivoire, Croatia, Cuba, Cyprus, Czech Republic, Democratic People's Republic of Korea, Democratic Republic of the Congo, Denmark, Djibouti, Dominica, Dominican Republic, Ecuador Egypt, Ed Salvador, Equatorial Guinea, Eritrea, Estonia, Ethiopia, Fiji, Finland, France, Gabon, Gambia, Georgia, Germany, Ghana, Greece, Grenada, Guatemala, Guinea, Guinea-Bissau, Guyana, Haiti, Honduras, Hungary, Iceland, India, Indonesia, Iraq, Ireland, Israel, Italy, Jamaica, Japan, Jordan, Kazakhstan, Kuwait, Kyrgystan, Lao People's Democratic Republic, Latvia, Lebanon, Lesotho, Liberia, Libyan Arab Jamahiriya, Liechtenstine, Lithuania, Luxembourg, Madagascar, Malawi, Malaysia, Maldives, Mali, Malta, Mauritius, Mexico, Mongolia, Morocco, Mosambique, Myanmar, Namibia, Nepal, Netherlands, New Zealand, Nicaragua, Niger, Nigeria, Norway, Panama, Papua New Guinea, Paraguay, Peru, Philippines, Poland, Portugal, Republic of Korea, Republic of Moldova, Romania, Russian Federation, Rwanda, Saint Kitts and Nevis, Saint Lucia, Saint Vincent and the Grenadines, Samoa, Saudi Arabia, Senegal, Seychelles, Sierrra Leone, Singapore, Slovakia, Slovenia, South Africa, Spain, Sri Lanka, Suriname, Sweden, Switzerland, Tajikistan, Thailand, The Forem Yugoslav Republic of Macedonia, Togo Trinidad and Tobago, Tunisia, Turkey, Turkmenistan, Tuvalu, Uganda, Ukraine, United Kingdom of Great Britain and Norther Ireland, United Republic of Tanzania, Uruguay, Uzbekistan, Vanuatu, Venezuela, Vietnam, Yemen, Yugoslavia, Zambia, and Zimbabwe. See id.

259. See Pakistan Press Intemational, NGO's Concern Over Forcible Marriage, (Jul. 20, 2000), available at LEXIS The Pakistan Newswire.

260. See Pakistan Basic Facts, supra note 19.

261. See RIZVI, supra note 27, at 227.

262. See PAL, supra note 76, at 9 . The Sharia Act was passed by the National Assembly in 1991, making it the supreme law of Pakistan. See id. Federal Shariat Court holds jurisdiction over cases where there is a questions of repugnancy of laws to the injunctions of Islam. See Pakistan Basic Facts, supra note 19.

263. See RIzVI, supra note 27, at 227. 
beliefs. ${ }^{264}$ However, the Shariat Courts were excluded from having jurisdiction over Constitutional, fiscal law, and legislation concerning personal status. ${ }^{265}$ In a well-known case, the Federal Shariat Court was banned from making binding decisions on land reform cases. ${ }^{266}$ Aside from these exceptions to the Shariat Court, this Islam-based judicial forum benefits Pakistan because an individual can bring a complaint to the Shariat Court or the Anglo-Saxon court system the State has set up. ${ }^{267}$

Justice is not free and is very time consuming in Pakistan. ${ }^{268}$ Overall, the credibility of the justice system in Pakistan is very low. ${ }^{269}$ Similar to other countries' judicial systems, Pakistan's judiciary is limited in resources by a backlog of cases. ${ }^{270}$ For every 1000 persons there are five cases pending. ${ }^{271}$ There is only one judge per every 85,000 persons, and on average every judge has some 450 cases pending. ${ }^{272}$ The backlog can mean wasted months as one waits for his case to eventually go through the court hearings and appeals process. ${ }^{273}$

\section{COMPARISON OF INDIA'S PANCHAYAT SYSTEM}

There are other countries that have tribal village councils acting as the official judiciary. ${ }^{274}$ India utilizes various legal cultures including: the traditional panchayat, which use customary law and procedures to settle disputes and maintain social control; the State legal system or adversary system; and a combination of the state system and the panchayat, called the

264. See Kluck, supra note 42, at 122.

265. See id.

266. See Kennedy, supra note 44, at 36, citing Hafiz Md. Ameen v. Islamic Republic of Pakistan, P.L.D. 1981 FSC 23. The Federal Shariah Court was banned from making binding decision on land reform cases. See id.

267. See Baxter, supra note 31 , at 3.

268. See Shaikh, supra note 140 , at 7.

269. See U.S. Dep't of State, supra note 19. The justice system is subject to not only executive and other outside influence by political and religious groups, but also corruption, inefficiency and lack of resources. See id. Some justices are threatened of being transferred if they do not respond in the manner the influential desire. See id.

270. See id.

271. See id.

272. See id. Court officials report that on an average day, a judge may review between seventy and eighty cases per day. See U.S. Dep't of State, supra note 19.

273. See NADEEM, supra note 3, at 271 . Case backlogs have led to extremely long delays in trials. See U.S. Dep't of State, supra note 19.

274. See Kimberly A. Klock, Resolution of Domestic Disputes Through Extra-Judicial Mechanisms in the United States and Asia: Neighborhood Justice Centers, The Panchayat and the Mahalla, 15 TEMP. INT'L \& COMP. L.J. 275, 285 (2001). In India and Uzbekistan, the panchayat and mahalla are extra-judicial structures that attempt to resolve issues of domestic violence and other community disputes by evaluating them they look at societal norms that influence social standing, the role of women in society, and effective punishment for the dispute. See id. 
Nyaya panchayat. ${ }^{275}$ The Constitution of India provides for the organization of village panchayats. ${ }^{276}$ In India, the panchayat is an example of a society where the power is held closest to the people. ${ }^{277}$ It is an institution in the rural areas that allows the tribes to govern themselves. ${ }^{278}$ The Constitution declared that a certain number of seats on the tribal council must be reserved for women so that the decisions rendered by the panchayat are sensitive to female issues. ${ }^{279}$ These councils have jurisdiction over disputes about agriculture, land reforms, soil conservation, water management, and maintenance of community assets. ${ }^{280}$ The village councils have the power to make decisions

275. See Theodore A. Mahr, An Introduction to Law and Libraries in India, 82 LAWLIBR. J. 91,107 (1990). The Nyaya panchayats are created by the State as an attempt for decentralization by formulating and implementing social change at the village level. See id. This form of legal system has decreased over the years. See id.

276. See INDIA CONST., available at http://parliamentofindia.nic.in (last visited Feb. 3, 2003). Part IX, 243B discusses the Constitution's directive:

There shall be constituted in every State, Panchayats at the village, intermediate and district levels in accordance with the provisions of this Part.

ld.

277. See Shalini Bhutani \& Ashish Kothari, The Biodiversity Rights of Developing Nations: A Perspective from India, 32 GOLDEN GATE U. L. REV. 587, 606 (2002).

278. See id. at 606.

279. See INDIA CONST. § 243D, supra note 276.

(1) Seats shall be reserved for-

(a) the Scheduled Castes; and

(b) the Scheduled Tribes, ...

(2) Not less than one-third of the total number of seats reserved under clause (1) shall be reserved for women belonging to the Scheduled Castes or, as the case may be, the Schedule Tribes.

(3) Not less than one-third (including the number of seats reserved for women belonging to the Scheduled Castes and the Scheduled Tribes) of the total number of seats to be filled by direct election in every Panchayat shall be reserved for women and such seats may be allotted by rotation to different constituencies in a Panchayat.

(4) The offices of the Chairpersons in the Panchayats at the village or any other level shall be reserved for the Scheduled Castes, the Scheduled Tribes and women in such manner as the Legislature of a State may, by law, provide:

Provided further that not less than one-third of the total number of offices of

Chairpersons in the Panchayats at each level shall be reserved for women.

Id. See also Klock, supra note 274, at 287.

280. See id. See INDIA Const., supra note 276 , art IX, \& 243G. Section detailing the powers, authority and responsibilities of the panchayats:

Subject to the provisions of this Constitution, the Legislature of a State may, by law, endow the Panchayats with such powers and authority as may be necessary to enable them to function as institutions of self-government and such law may contain provisions for the devolution of powers and responsibilities upon Panchayats at the appropriate level, subject to such conditions as may be specified therein, with respect to-

(a) the preparation of plans for economic development and social justice;

(b) the implementation of schemes for economic development and social justice as may be entrusted to them including those in relation to the matters listed in the Eleventh Schedule.

Id. 
on the biological resources of the community and they are to be consulted with regard to decisions on development of their lands. ${ }^{281}$ In contrast, Pakistan utilizes these village councils to resolve family and civil disputes. ${ }^{282}$ The 1996 Panchayat Act further regulated the process of Indian tribal councils. ${ }^{283}$ This Act extended the self-government regulations to the tribal areas of India. ${ }^{284}$

In India, the panchayat process consists of meetings, consultations, and discussions with different leaders of the community. ${ }^{285}$ Similar to Pakistan's jirgas, mediation and conciliation are used to resolve disputes and achieve justice. ${ }^{286}$ Finding a resolution through consensus and nonviolence has been the traditional foundation of Indian justice. ${ }^{287}$ However, in contrast, when the panchayat hears the case, the village council and community as a whole are brought together for a compromise. ${ }^{288}$ The adversary court system renders a decision that is free of community opinion and they often have problems ascertaining the facts. ${ }^{289}$ Yet, the panchayat is more productive because the individuals that are involved in the case have personal knowledge of the case. $^{290}$

India utilizes the panchayat for the purpose of bringing satisfaction to the parties involved and the community. ${ }^{291}$ It is a tradition that is controlled by the village elite. ${ }^{292}$ There is no court reporter to record the process. ${ }^{293}$ The panchayat does not use case precedence in determining decisions. ${ }^{294}$ Because there is no binding precedence or preservation of case law, the justice system was decentralized to the village level where the community determined the law. ${ }^{295}$

281. See id. at 606.

282. See Cheri M. Ganeles, Cybermediation: A New Twist On An Old Concept, 12 AL.B. L.J. SCI. TECH. 715, 722 (2002).

283. See The Provisions of the Panchayats (Extension to the Scheduled Areas) Act, 1996 available at http://ncscst.nic.in/panchayats.htm (last visited Feb. 3, 2003). See Klock, supra note 274 , at 286 .

284. See Bhutani \& Kothari, supra note 277, at 606. The 1996 Panchayat Act provided villages with more substantive input in the decision-making process. See id. The Act clearly distinguished consultation from the more desired meaningful participation. See id.

285. See Klock, supra note 274, at 285.

286. See Mahr, supra note 275 , at 95.

287. See id. The Indian citizens compromised quite often because the preservation of the autonomy and peace of the caste or tribe took precedence over an individual's rights and duties. See id. Although the panchayats are consensual, the majority could not impose their decision upon a party, the decision must be agreed upon by everyone in the panchayat. See id.

288. See Mahr, supra note 275 , at 103.

289. See id. at 104.

290. See id.

291. See id.

292. See id.

293. See Klock, supra note 274 , at 286.

294. See id.

295. See Mahr, supra note 275 , at 99. 


\section{ABOLISH OR REFORM?}

Many human rights organizations and others would like to see these Pakistani tribal councils eliminated. ${ }^{296}$ The widespread use of extra-judicial verdicts sanctioning gang rape and other human rights abuses has led to international condemnation and domestic opposition. ${ }^{297}$ Despite the fact that the State officials indicate that they will not tolerate the human rights abuses at the hands of jirgas, their actions tend to counter this indication. ${ }^{298}$ Local governmental leaders and members of political parties participate and support the tribal councils. ${ }^{299}$ Incredulously, a former federal secretary and a new District Coordination Officer actually attended a jirga in $2001 .^{300}$

In the United States, alternative dispute resolution mechanisms are popular and effectively and efficiently resolve the disputes while eliminating the backlog of cases. ${ }^{301}$ Consequently, access to the U.S. justice system has increased with more disputes being resolved. ${ }^{302}$ Similarly, allowing an alternative dispute resolution program utilizing the panchayat system could alleviate the constraint and overload on the Pakistani judicial system. ${ }^{303}$ The informal revival of the panchayat system, although illegal, has resolved some disagreements that have been ongoing for several years whereby several opposing tribal members were murdered. ${ }^{304}$ Consequently, these resolutions have put an end to the further loss of life. ${ }^{305}$ In one example, a dispute ongoing for eight years between two warring tribes cost the lives of six tribal members. ${ }^{306}$ A tribal council was called and the dispute was resolved within four hours with monetary compensation to the families whose kin were murdered. ${ }^{307}$ In order to deter the tribes from continuing with their dispute, the jirga often orders steeper penalties if the resolution is breached or disregarded and the parties end up before the council in the future. ${ }^{308}$

The government cannot meet the efficient and timely trials requirement because of its limited resources and the frequent demand for justice. ${ }^{309}$ Thus, if the workload of the police and court system were reduced, the effectiveness

296. See Sheikh, supra note 1.

297. See TALBOT, supra note 51, at 283.

298. See Amnesty, supra note 10.

299. See id. A Federal Law Minister defended the jirgas as being a cultural tradition which had its merits even though women often were victims of the councils. See id.

300. See id.

301. See Klock, supra note 274, at 275.

302. See id.

303. See discussion, infra Note VI. See also NADEEM, supra note 3, at 271.

304. See id. at 237.

305. See id.

306. See Amnesty, supra note 10.

307. See id. The tribal courts reach decisions very quickly with even more complicated disputes resolved in a matter of days. See id.

308. See Amnesty, supra note 10.

309. See NADEEM, supra note 3, at 272. 
of the police and the judiciary would increase. ${ }^{310}$ By handing over less important cases to the tribal councils, police are able to respond to the more serious crimes. ${ }^{311}$ Furthermore, their efficiency will naturally improve when they are only dealing with a fraction of their original workload. ${ }^{312}$

The process should bring both parties forward to discuss any direct or circumstantial evidence relative to the dispute; and keeping with the customs and traditions of the social conditions, the resolution is more likely to be suitable to both parties. ${ }^{313}$ In successful resolutions, the local police and the respected tribal officials were involved in the compromise that brought reconciliation between the parties. ${ }^{314}$ The restoration of the tribal councils can greatly benefit the rural sector of society, plagued with the long delays and the huge expenses that are involved when seeking justice even when the dispute is minute. ${ }^{315}$

It is expected that rural areas would greatly benefit from the revival of the panchayats because the majority of the flare-ups are temporary and not longstanding whereas both sides are willing to compromise and resolve the situation. ${ }^{316}$ Yet, if the local police and justice system handle the case, the dispute would be ongoing with great loss of time, money, and energy while waiting for the investigation and court proceedings. ${ }^{317}$ The tribal council is likely to be successful at finding a settlement in a matter of a few days. ${ }^{318}$

\section{OTHER SOCIAL FACTORS FOR CONSIDERATION}

\section{A. Education}

In order to overcome cultural and social concern, the Pakistan government must attack this custom of unofficial justice and promote education. ${ }^{319}$ Unfortunately, according to the 1981 Census, only fifteen percent $(15 \%)$ of the rural population over the age of ten years old is literate. ${ }^{320}$

Education plays a big role in giving the poor a voice to bring awareness to the issues that plague their communities. ${ }^{321}$ As a result, they are able to

310. See id.

311. See id.

312. See id.

313. See id.

314. See id. at 237.

315. See NADEEM, supra note 3, at 237.

316. See id. at 272.

317. See id.

318. See id. See also Amnesty, supra note 10.

319. See Paringaux, supra note 79.

320. See Kluck, supra note 42 , at 125 . Within rural areas, the female literacy rate is two percent or less. See U.S. Dep't of State, supra note 19. Overall, thirty-three percent (33\%) of the population are found to be literate when using a very low standard. See id.

321. See NADEEM, supra note 3, at 51. 
articulate their concerns, make suggestions and voice complaints in a manner that is socially acceptable. ${ }^{322}$

High rates of illiteracy can lead to communication problems with the police. ${ }^{323} \mathrm{~A}$ widely recognized case involving a woman who was raped by her husband's brother was taken to the police office to register a FIR on March 26, $2001{ }^{324}$ Unbeknownst to her, the father-in-law, who did all the talking to the police officers, did not name his son as the culprit, but named another man. ${ }^{325}$ The FIR contained the woman's thumbprint, which leads one to believe that she was illiterate since she did not sign the report. ${ }^{326}$ After her father-in-law gave the statement, she was immediately arrested and went to trial for adultery. ${ }^{327}$

Currently, there is a massive need to educate a rapidly growing population in Pakistan. ${ }^{328}$ Schools, teachers, and textbooks are limited in supply as compared to their demand. ${ }^{329}$ If young girls go to school, they are only allowed to attend school until puberty. ${ }^{330}$ However, problems may arise if women are urged to seek out an alternative life style. ${ }^{331}$ The women may feel safe and stable under the confines of purda. ${ }^{332}$ Nonetheless, social change can occur by overcoming illiteracy by establishing more schools, colleges and universities for all persons of Pakistan. ${ }^{333}$

\section{B. State Role}

The social environment in which the tribal council exists is an important factor in the effectiveness of the panchayat. ${ }^{334}$ The panchayat evaluates the issues by looking at the norms in the society that influence social standing. ${ }^{335}$ However, when the panchayat violates the human rights of tribal members, the State must take action against those councils that orders the rapes or honor

322. See id.

323. See id.

324. See Int'l Network for the Rights of Female Victims of Violence in Pakistan, Zafran Bibi Case: Background \& Legal Information, available at http://inrfvvp.org/cases/zafran_ bibi.html (last visited Feb. 3, 2003).

325. See id.

326. See id.

327. See id. After the woman exonerated the innocent man, the court found her guilty of adultery and sentenced her to death by stoning. See id. However, it is likely that the Federal Shariat Court will overturn the sentence when the appeal is heard. See id.

328. See TALBOT, supra note 51, at 221-22. It is not possible for the formal education system to keep up with the challenges of rapidly increasing population. See 2001 Economic Survey, supra note 54.

329. See id.

330. See THE SINDH PERCHAR, supra note 99 , at 9.

331. See PAL, supra note 76, at 129.

332. See id.

333. See KIBRIA, supra note 117 , at 2 .

334. See Klock, supra note 274 , at 291.

335. See id. at 285. 
killings. ${ }^{336}$ Where women are included in the tribal councils, they provide insight into the role that women play in society. ${ }^{337}$ The Pakistan government fails to sensitize the police and judiciary to the role of women in society. ${ }^{338}$

The local police need to remove fears and create interactive relationships where the police are accessible and visible. ${ }^{339}$ Being the agency that is ultimately responsible for the prevention and detection of crime, the police force should be efficient and held accountable while gaining the confidence and respect of the local citizens. ${ }^{340}$ The police should foster a close and supportive relationship with the public so that the public is more willing to share information regarding incidents, thereby reducing the potential crimes from occurring. ${ }^{341}$ Additionally, a multi-agency approach combining sources from social, economic, cultural, and educational agencies can lead to a proactive collaboration to develop solutions by looking at the root causes rather than the symptoms of crime. ${ }^{342}$

The Punjab Police Department set up women complaint centers to address the lack of attention by the police of solving crimes against women and apprehending the perpetrators. ${ }^{343}$ The types of complaints that can be registered with these centers are household disputes, crimes where women are either victims or the accused, and requests to escort women to the courts or hospitals. ${ }^{344}$

Evidentiary standards will also need to be developed for the tribal councils in order for them to effectively serve in a judicial role. ${ }^{345}$ The tribal jirgas have used the act of walking over burning coals to determine guilt of innocence. ${ }^{346}$ In some cases, if the accused was able to walk over the burning coals without getting burned, he was declared innocent and released ${ }^{347}$ An automatic declaration of guilt was rendered if the defendant was unable to

336. See Amnesty, supra note 10. By delivering the death sentence to the individuals who gang-raped the Gujjar woman, the ATC hopes to deter other panchayats from rendering similar punishments. See Shamsie, supra note 165.

337. See Klock, supra note 274 , at 286.

338. See THE SINDH PERCHAR, supra note 99, at 1.

339. See id. at 224.

340. See id. at 214. Currently, when allegations of rape and abuse by the police force have been brought to the attention of authorities, the officers are generally transferred or suspended for their actions. See U.S. Dep't of State, supra note 19. Not one police officer has ever been convicted of police abuse, rape or extrajudicial killings. See id.

341. See NADEEM, supra note 3, at 218.

342. See id. at 219.

343. See Government of Punjab, Police Department, at http://www.punjab.gov.pk/police/ women_complaints.htm, (last visited Nov. 19, 2002).

344. See id.

345. See Amnesty, supra note 10.

346. See id.

347. See id. 
walk over the burning coal or if he was burnt in the process. ${ }^{348}$ Clearly this is an inhumane and ineffective way of determining the guilt of a party. ${ }^{349}$

Because the tribes are not official courts, there is no legislation governing them. ${ }^{350}$ Consequently, women are not allowed to attend the jirgas nor are they allowed to serve as witnesses. ${ }^{351}$ Other than traditional or customary rules that the tribes follow, there are no references or uniform codes to offer panchayats guidance. ${ }^{352}$ Some moves have been made to develop a uniform code of conduct for the jirgas to follow in order to settle tribal disputes. ${ }^{353}$ However, the uniform code should be passed through legislation to reinforce the interaction between the State and the tribal councils. ${ }^{354}$

\section{Decentralization}

The Pakistan Constitution encourages local Government institutions. ${ }^{355}$ Other countries have already taken steps to amend their laws to decentralize government. ${ }^{356}$ Citizens interact at the local level with the governmental structures on a daily basis. ${ }^{357}$ The national government is removed from the experiences of the daily life. ${ }^{358}$ Thus, citizens rely on the local level government for their needs and problems. ${ }^{359}$ Thus, Pakistan could benefit from a decentralized government, which gives the local government councils the power to initiate programs. ${ }^{360}$

However, local governments are very weak and their position is not only affected by a lack of resources but also by an inadequate legal framework. ${ }^{361}$ Many governments fail to provide the services needed on a local level on a regular basis. ${ }^{362}$ Thus, if the local government meets the needs of the local

348. See id.

349. See id.

350. See id.

351. See Amnesty, supra note 10.

352. See id. Panchayats rely on unwritten, customary law. See Mahr, supra note 275, at 109. Written law as reference has never been important for panchayats or tribal councils because they rely on unwritten, customary law. See id.

353. See Amnesty, supra note 10. In 1998, all of the Upper Sindh tribes were invited to develop a uniform code of conduct for jirgas to use. See id. The next appointed Commissioner further laid the foundation to assist the jirgas in resolving disputes. See id.

354. See id.

355. PAK. CONST. (1973), \& 32.

356. See Walter Kaelin, Legal Aspects of Decentralisation in Pakistan, available at $\mathrm{http}: / \mathrm{www}$.preventconflict.org/portal/centralasia/issuelist.php?i=2069\&r=2004 (last visited Oct. 7, 2002) (copy on file with author). India has amended its Constitution in 1992 with a long chapter on village panchayats. See id. The Philippines and Sri Lanka also are showing a strong trend to strengthen their local governments. See id.

357. See id.

358. See id.

359. See id.

360. See Kaelin, supra note 356.

361. See id.

362. See id. 
citizens, the programs and services can be more easily adapted to the particular circumstances and needs of the local area. ${ }^{363}$ Ultimately, the close relationship that is developed between the citizens and the local governments fosters accountability of the government which thereby helps prevent the governmental agents from abusing their powers. ${ }^{364}$ In addition, the decision making process is kept close to the people, building a sense of community and permitting more meaningful participation in self-government. ${ }^{365}$ The distribution of power to different levels of government, as well as the threatening competition to attain the power, allows for a system of checks and balances; this ensures that the central government does not overstep or abuse its powers. ${ }^{366}$

The Ombudsman's Office and the Minister of Women's Affairs are two governmental agencies that can work with local tribes on social and education problems. ${ }^{367}$ A separate office of Ombudsperson for Women should be created to deal with complaints of ill treatment toward women exclusively. ${ }^{368}$ Community involvement should include participation in consultation groups, victim support programs, crime prevention groups, and interactive relations with the local business community. ${ }^{369}$ Consultation groups should include individuals that are elected to serve but non-elected should be involved also. ${ }^{370}$ Yet, decentralization does not automatically mean that a better administration will be developed and maintained. ${ }^{371}$ The local governments must be properly equipped to fulfill their responsibilities. ${ }^{372}$ In order to create stability among the local government, an amendment to the Constitution could prevent the provincial governments from weakening the local governments. ${ }^{373}$

\section{CONCLuSION}

It is definite that the effect of Pakistan's lawlessness affects the social, political and economic aspects of the State. ${ }^{374}$ Countries without law and order problems, generally, benefit greatly from economic stability and growth. ${ }^{375}$ It

363. See id.

364. See id.

365. See id.

366. See Kaelin, supra note 356.

367. See PAKISTAN GOVERNMENT, Responsibilities Covering Human Rights, available at http://www.pak.gov.pk/public/govt/resp_humanright.htm (last visited Feb. 3, 2003).

368. See id.

369. See NADEEM, supra note 3, at 264.

370. See id.

371. See Kaelin, supra note 356.

372. See NADEEM, supra note 3, at 264.

373. See Kaelin, supra note 356 . Local governments cannot function properly if the higher levels of government can dissolve them easily or are able to change their territories. See id.

374. See NADEEM, supra note 3, at 137-38.

375. See id. at 1. 
is believed that Pakistan has three routes it can take into the future. ${ }^{376}$ First, Pakistan can simply continue to exist in a state of lawlessness. ${ }^{377}$ Second, the government can respond by restructuring the social and political policies in order for Pakistan to fulfill the destiny predicted when the nation was born in $1947 .{ }^{378}$ In order to do this, Pakistan needs to exercise justice so that all persons, whether male or female, as well as different caste members, can feel safe. ${ }^{379}$ In addition, the corruption of the government and police officials needs to be challenged and the citizens need to learn tolerance. ${ }^{380}$ Society must combat intolerance and eliminate the catering to the ethnic and religious demands. ${ }^{381}$ Furthermore, there must be a conscious de-escalation of the discrimination of hatred based on cultural, social, religious and political. ${ }^{382}$

Finally, Pakistan can apply temporary fixes to the social structure in order to survive without making any meaningful changes. ${ }^{383}$ Unfortunately, this may be the path that Pakistan will choose. ${ }^{384}$ If actions are taken to reform the abuse of human rights with respect to lower castes, it is likely this would lead to violence in the community. ${ }^{385}$ Thus, the social norms which have dictated their culture and communities for years is the accepted way of life. ${ }^{386}$

Citizens in Pakistan must take positive social and moral measures by fighting the caste system and feudalism. ${ }^{387}$ Economic development can also increase as confidence is built among the citizens as well as foreign investors. ${ }^{388}$ The time has come to reform the feudal system where some families dominate society as a whole. ${ }^{389}$ The government needs to step in and curb the patronage that is given to feudal landlords. ${ }^{390}$

Pakistan should readjust its budget spending to properly allocate funds to promote social and economic growth. ${ }^{391}$ The Ministry of Finance ${ }^{392}$ conducted an economic survey indicating that education is the cornerstone of

376. See AHMED, supra note 94, at 251.

377. See id. at 251-52.

378. See id.

379. See id.

380. See id.

381. See id. at 252. See Shamsie, supra note 165.

382. See AHMED, supra note 94, at 252.

383. See id.

384. See id.

385. See id.

386. See id.

387. See KIBRIA, supra note 117, at 226.

388. See NADEEM, supra note 3 , at 138.

389. See id. at 307.

390. See id.

391. See U.S. Dep't of State, supra note 19. Progress in certain areas can only be made in the long term with significant resource commitments. See id.

392. See PAKISTAN GOVERNMENT, available at http://www.pakistan.gov.pk/MinDiv.jsp (last visited Nov. 15, 2002). The Ministry of Finance is a department of the Pakistan government. See id. The Ministry of Finance deals with economic affairs such as revenue and planning and development. See id. 
economic growth and poverty reduction. ${ }^{393}$ Education can play a huge role in reform by allocating proper funding to programs to educate society. ${ }^{394}$ It appears that Pakistan initiated this process by allocating more funds for the rehabilitation of existing school facilities. ${ }^{395}$ The government has high hopes that this focus on education will increase the literacy rate to sixty percent $(60 \%){ }^{396}$

Decentralizing the government to enable local governments to play the role of oversight of the tribal councils has the potential to provide autonomy for traditional religions, political minorities or ethnic minorities. ${ }^{397}$ This allows local government to create local laws that affect the tribes and their lands. ${ }^{398}$ A successful decentralization will need a secure existence including accountability to the citizens as well as the higher governments, and partnership between the central and local governments. ${ }^{399}$ A multi-agency crime enforcement and prevention program can resolve some of the fears of the police force ${ }^{400}$ It could change the public perception and reduce the incidents of violence. ${ }^{401}$ The police should prevent crimes, detect offenses, maintain order, and keep the peace. ${ }^{402}$ They should also administer justice, not deny civil liberties, engage in reprisals, or terrorize the communities. ${ }^{403}$

Similar to India's panchayat system, further amendments to the Pakistan Constitution should be made to provide legislation that the tribal councils can utilize as reference or guidance. ${ }^{404}$

Nonetheless, a federal judiciary will need to provide assistance to minorities to ensure that their political or cultural rights are enforced at the local levels of government. ${ }^{405}$ There needs to be public confidence in the criminal justice system, which maintains a proper balance between the rights of the citizens and the needs of the community as a whole. ${ }^{406}$ The State judiciary should also monitor the actions of the tribal councils. ${ }^{407}$

393. See 2001 Economic Survey, supra note 54.

394. See NADEEM, supra note 3 , at 52 . Education is seen as the key to progress and economic growth can be achieved with a higher emphasis on the quality of its human capital. See 2001 Economic Survey, supra note 54.

395. See id. An amount of 1.57 billion rupees has been allocated from the 2001-02 budget for educational services. See id.

396. See id.

397. See Kaelin, supra note 356.

398. See id.

399. See id.

400. See NADEEM, supra note 3, at 215.

401. See id. at 215.

402. See id. at 309.

403. See id.

404. See INDIA CONST., supra note 276 , art. IX. India has provided reference for the panchayats to follow when self-governing. See id.

405. See Kaelin, supra note 356.

406. See NADEEM, supra note 3, at 302-03.

407. See id. 
Women must be empowered to serve as members of the tribal councils where they are able to form opinions and address issues according to the female perspective and not simply what their husbands dictate. ${ }^{408}$ Current relationships between women and men do not reach beyond the external society outside of their households. ${ }^{409}$ Thus, if there were frequent interaction between women and men, society may benefit by changing the cultural atmosphere that has hindered the equality of women in the tribal regions. ${ }^{410}$

In India, the Constitution requires that a certain number of seats on the panchayats be reserved for women so that their views are reflected in the decision made by the local governments. ${ }^{411}$ Some non-governmental organizations began programs that attempted to bring legal help to rural women to empower them to question the discriminatory cultural norms sanctioned by these tribal councils. ${ }^{412}$ In addition, positive responses have been received regarding a task force for the Rural Support Programme ${ }^{413}$ in northern areas of the country. ${ }^{414}$ Although the program has mainly dealt with alleviating poverty, it is recognized that these programs should be expanded to deal with other issues such as gender discrimination and human rights violations. ${ }^{415}$

Female participation in the administration of affairs at educational institutions is an important step toward social growth. ${ }^{416}$ This would enable women to play a role in the new community while creating a new consciousness of the human rights of women provided for in Pakistan's Constitution. ${ }^{417}$ Healthier and better-educated women would be more able to fulfill their roles of cultural and biological transmission. ${ }^{418}$

408. See U.S. Dep't of State, supra note 19. Pakistan has initiatives to empower women by increasing women's participation in local governments. See id. The government has reserved one-third of the seats of local governing bodies for women. See id. See also Rawalpindi: Need For Women Empowerment Stressed, DAWN, Nov. 22, 2002, available at http://www.dawn.com/2002/11/22/local 14.htm (last visited Feb. 3, 2003) [hereinafter DAWN].

409. See PAL, supra note 76, at 129.

410. See DAWN, supra note 408.

411. See Kaelin, supra note 356.

412. See Bari \& Khattak, supra note 87 , at 235 . The NGO's have begun programs such as Law and Status Programme which encourages women to use law for the protection of their rights. See id.

413. See National Rural Support Programme, available at http://www.nrsp.org.pk/ (last visited Nov. 19, 2002). The NRSP was set up in November 1991 as a non-profit organization to undertake development activities in the rural areas of Pakistan. See id. The main objective of the program is to foster a countrywide network of grassroots level organizations to enable rural communities to plan, implement and manage developmental activities for the purpose of ensuring productive employment, alleviation of poverty and improvement in the quality of life. See id. 413.

414. See Khan, supra note 57, at 284. See National Rural Support Programme, supra note

415. See id.

416. See TALBOT, supra note 51 , at 57 . Those countries that facilitated women in education and other sectors earned respect in the international community.

417. See id.

418. See id. 
Finally, the government should establish the systems and procedures to ensure that a local tribal council program is not in violation of any human rights. ${ }^{419}$ Human development strategies stress the importance of institutions for improving human rights conditions. ${ }^{420}$ This can only be done through proper supervision and monitoring of the panchayats. ${ }^{421}$ The State must provide better training to enhance the professionalism of the tribal council members. ${ }^{422}$ Subsequently, the establishment of a participatory institution of police and judiciary at a community level will strengthen law and order in the region. ${ }^{423}$ If the police had performed their assigned roles in the community, rather than allowing crime and injustice to be committed, then maybe a young woman would not have been gang-raped and forced to walk home naked through the streets of the community. Furthermore, maybe more women would come forward to file a complaint with the police and feel confident that the investigation would be handled with accordance to the law.

The revival of the panchayat system could be very advantageous in preserving law and order in Pakistan while ensuring an environment conducive to economic and social growth. ${ }^{424}$ President Musharraf's government has given human rights organizations encouragement by focusing on the violations such as rape and honor killings that have been at the hand of the jirgas. ${ }^{425}$ Tribal councils must abide by the Pakistan Constitution and other international human rights treaties that Pakistan has ratified. ${ }^{426}$ The maintenance of law and order can effectively be monitored by an interaction of the State and society, and ultimately further the Constitutional standard of protecting life, liberty and property. ${ }^{427}$

Marie D. Castetter

419. See NADEEM, supra note 3, at 302.

420. See id. at 17 .

421. See id. at 302.

422. See id.

423. See id.

424. See id. at 343.

425. See Joseph, supra note 199.

426. See Amnesty, supra note 10. CEDAW, states that:

State Parties shall take all appropriate measures:

(a) To modify the social and cultural patterns of conduct of men and women, with a view to achieving the elimination of prejudices and customary and all other practices which are based on the idea of the inferiority or the superiority of either of the sexes or on stereoptyped roles for men and women.

See CEDAW, supra note 256, art. 5, part 1.

427. See NADEEM, supra note 3, at 17.

* J.D., Indiana University School of Law - Indianapolis, 2004 (expected); B.S. in Organizational Leadership, Purdue University, 1997. The author would like to extend thanks to her husband and family for their support and encouragement throughout this project. 